\title{
Skeletal muscle protein anabolic response to resistance exercise and essential amino acids is delayed with aging
}

\author{
Micah J. Drummond ${ }^{1}$, Hans C. Dreyer ${ }^{1,2}$, Bart Pennings ${ }^{4}$, Christopher S. Fry ${ }^{1}$, Shaheen \\ Dhanani ${ }^{3,4}$, Edgar L. Dillon ${ }^{3,4}$, Melinda Sheffield-Moore ${ }^{3,4}$, Elena Volpi ${ }^{3,4}$, and Blake B. \\ Rasmussen $1,2,4$ \\ ${ }^{1}$ Division of Rehabilitation Sciences, University of Texas Medical Branch, Galveston, Texas \\ ${ }^{2}$ Department of Physical Therapy, University of Texas Medical Branch, Galveston, Texas \\ ${ }^{3}$ Department of Internal Medicine, University of Texas Medical Branch, Galveston, Texas \\ ${ }^{4}$ Sealy Center on Aging, University of Texas Medical Branch, Galveston, Texas
}

\begin{abstract}
Skeletal muscle loss during aging leads to an increased risk of falls, fractures, and eventually loss of independence. Resistance exercise is a useful intervention to prevent sarcopenia; however, the muscle protein synthesis (MPS) response to resistance exercise is less in elderly compared with young subjects. On the other hand, essential amino acids (EAA) increase MPS equally in both young and old subjects when sufficient EAA is ingested. We hypothesized that EAA ingestion following a bout of resistance exercise would stimulate anabolic signaling and MPS similarly between young and old men. Each subject ingested $20 \mathrm{~g}$ of EAA $1 \mathrm{~h}$ following leg resistance exercise. Muscle biopsies were obtained before and 1,3 , and $6 \mathrm{~h}$ after exercise to measure the rate of MPS and signaling pathways that regulate translation initiation. MPS increased early in young (1-3 $\mathrm{h}$ postexercise) and later in old (3- $6 \mathrm{~h}$ postexercise). At $1 \mathrm{~h}$ postexercise, ERK1/2 MNK1 phosphorylation increased and eIF2 $\alpha$ phosphorylation decreased only in the young. mTOR signaling (mTOR, S6K1, 4E-BP1, eEF2) was similar between groups at all time points, but MNK1 phosphorylation was lower at $3 \mathrm{~h}$ and AMPactivated protein kinase- $\alpha$ (AMPK $\alpha$ ) phosphorylation was higher in old 1-3 h postexercise. We conclude that the acute MPS response after resistance exercise and EAA ingestion is similar between young and old men; however, the response is delayed with aging. Unresponsive ERK1/2 signaling and AMPK activation in old muscle may be playing a role in the delayed activation of MPS. Notwithstanding, the combination of resistance exercise and EAA ingestion should be a useful strategy to combat sarcopenia.
\end{abstract}

\section{Keywords}

sarcopenia; mammalian target of rapamycin; AMPK; weight lifting

aging in humans is Characterized by a gradual loss in skeletal muscle strength and fiber size (1). The loss of skeletal muscle (termed sarcopenia) occurs at a rate of $~ 5 \%$ per decade after the age of 30 and accelerates with advancing age $(22,37)$. From a practical standpoint, this could lead to an increased risk of falls and fractures (43) and eventually loss of independence (26). It is estimated that approximately one-quarter to one-half of the population of men and women aged

Copyright $@ 2008$ the American Physiological Society

Address for reprint requests and other correspondence: B. B. Rasmussen, Univ. of Texas Medical Branch, Dept. of Physical Therapy, Division of Rehabilitation Sciences, 301 Univ. Blvd., Galveston, TX 77555-1144 (e-mail: E-mail: blrasmus@utmb.edu).. 
65 and older are sarcopenic $(2,24)$. Given our rapidly aging population, research designed to better understand the development, progression, and treatment of sarcopenia is of substantial importance.

Physical activity is a key factor in reducing physical disability $(16,35)$. Resistance exercise training appears to be a reliable intervention to protect against the effects of age-related muscle loss. Repeated bouts of resistance exercise are well known to increase protein synthesis (20, $61,62)$ and skeletal muscle mass $(15,32)$ in young and old adults. However, the increase in muscle protein synthesis with resistance exercise training in the old is lower than young (54). Furthermore, $16 \mathrm{wk}$ of resistance exercise training increased strength and type II muscle fiber size in old adults, but the growth response in these subjects was less compared with young subjects (32). In a recent study we showed that protein synthesis does not change 1 or $3 \mathrm{~h}$ after a single bout of resistance exercise in old men (44). This is in contrast to young muscle, which responds robustly (increased protein synthesis) to an acute bout of resistance exercise (13).

A key intracellular pathway coordinating signals in the regulation of protein synthesis is the mammalian target of rapamycin (mTOR) (6). mTOR signaling to its downstream effectors, ribosomal S6 kinase 1 (S6K1) and 4E binding protein 1 (4E-BP1), plays a key regulatory role in the regulation of translation initiation (53). Following resistance exercise in animals and humans, components of the mTOR pathway are rapidly up-regulated $(8,13,14,34)$. Unfortunately, there are no data in aged human skeletal muscle describing mTOR signaling mechanisms following a single bout of resistance exercise. It has been reported that mTOR signaling is not altered in old rodent skeletal muscle following intermittent passive stretch used as a source of mechanical stimulation (23); however, other studies have shown that the activation of mTOR signaling following resistance exercise in old rats is reduced $(19,39)$.

On the other hand, AMP-activated protein kinase (AMPK) appears to be a negative regulator of protein synthesis (7). The level of inhibition occurs via the phosphorylation and, hence, activation of TSC2, a direct inhibitor of mTOR (25). We have recently identified that muscle protein synthesis decreases and AMPK activity increases during a bout of resistance exercise in young subjects (13). Furthermore, AMPK $\alpha$ phosphorylation is elevated in aged rodent skeletal muscle and after muscle overload compared with their younger counterparts (46). This suggests that AMPK may play a role in regulating the protein anabolic response in skeletal muscle between young and old humans following resistance exercise.

Resistance exercise can also activate the mitogen-activated protein kinase (MAPK) signaling pathway in human skeletal muscle (57), a key signaling pathway that has also been associated with enhanced protein synthesis $(17,58)$ but independent of mTOR $(17)$. Williamson et al. (57) demonstrated in young and old humans that resistance exercise increased the phosphorylation of key MAPK signaling proteins including extracellular regulated kinase 1 and 2 (ERK1/2) and mitogen-activated protein kinase-interacting kinase 1 (MNK1). Interestingly, in this same study, the general MAPK response appeared to be significantly different at baseline and following exercise between the age groups (57).

It has been reported that muscle from older individuals is resistant to the anabolic effects of amino acids (11). However, we have shown that the ingestion of a sufficient amount (>15 g) of essential amino acids (EAA) stimulates muscle protein synthesis to a similar extent in young and old subjects $(38,51,52)$. We have recently reported that skeletal muscle protein synthesis and mTOR signaling are stimulated in young subjects following the ingestion of leucineenriched EAA and carbohydrates (18). In fact, several studies show that muscle protein synthesis is enhanced in young subjects when EAAs or protein are ingested following resistance exercise $(3,9,14,21,30,31,40,48,56)$. Recently, it has been shown that the ingestion (multiple boluses over a 6-h time frame) of protein and carbohydrate following activities of 
daily living stimulated muscle protein synthesis in young and old men (30). Therefore, the combination of more potent activators of muscle protein synthesis (resistance exercise and EAA) in old individuals may be useful in restoring the acute muscle protein synthesis response, and potentially muscle hypertrophy, to youthful levels.

Therefore, we hypothesized that a leucine-enriched EAA ingestion following an acute bout of resistance exercise would stimulate anabolic signaling and muscle protein synthesis to a similar extent between young and old men.

\section{METHODS}

\section{Subjects}

We studied seven young and six old male subjects (age range: 24-77 yr). Subject characteristics are found in Table 1 . The subjects were not engaged in any regular exercise training at the time of the enrollment; however, they were physically independent and overall healthy. Screening of subjects were performed with clinical history, physical exam, and laboratory tests including complete blood count with differential, liver, and kidney function tests, coagulation profile, fasting blood glucose and oral glucose tolerance test, hepatitis B and C screening, human immunodeficiency test, thyroid stimulating hormone test, urinalysis, drug screening, electrocardiogram, and stress test on a treadmill or bicycle. Subjects were also tested for maximal strength by performing a one-repetition maximum (1RM) on a leg extension machine (Cybex-VR2, Medway, MA) during the initial screening. A second 1RM testing was performed at least $1 \mathrm{wk}$ prior to study participation. The starting weight used during the resistance exercise portion of this study was $70 \%$ of the subjects' predetermined 1RM. All subjects gave informed, written consent before participating in the study, which was approved by the Institutional Review Board of the University of Texas Medical Branch (which is in compliance with the Declaration of Helsinki).

\section{Study design}

All subjects were admitted to the General Clinical Research Center (GCRC) of the University of Texas Medical Branch the day prior to the exercise study, and a dual-energy X-ray absorptiometry scan (Hologic QDR 4500W, Bedford, MA) was performed to measure body composition and lean mass. The subjects were then fed a standard dinner and a snack at 2200 . All subjects were studied following an overnight fast under basal conditions and refrained from exercise for $24 \mathrm{~h}$ prior to study participation. The morning of the infusion study, an 18-gauge polyethylene catheter was inserted into a forearm vein for tracer infusion and another catheter was inserted retrogradely in the forearm of the opposite arm, which was heated for arterialized blood sampling. After a background blood sample was drawn, a primed continuous infusion of $\mathrm{L}_{-}\left[\right.$ring $-{ }^{2} \mathrm{H}_{5}$ ] phenylalanine (Cambridge Isotope Laboratories, Andover, MA) was started (time $=0 \mathrm{~h}$ ) and maintained at a constant rate until the end of the experiment (Fig. 1). The priming dose for the labeled phenylalanine was $2 \mu \mathrm{mol} / \mathrm{kg}$ and the infusion rate was 0.05 $\mu \mathrm{mol} \cdot \mathrm{kg}^{-/-1} \cdot \mathrm{min}^{-1}$. All subjects were studied during the same time of day to avoid potential circadian changes.

A baseline muscle biopsy was taken $2 \mathrm{~h}$ following the initiation of the tracer infusion. The biopsy was obtained from the lateral portion of the vastus lateralis using a 5-mm Bergström biopsy needle, under sterile procedure and local anesthesia (1\% lidocaine). Once harvested, the muscle tissue was immediately blotted and frozen in liquid nitrogen and stored at $-80^{\circ} \mathrm{C}$ until analysis. Following the first biopsy, two blood samples were drawn $30 \mathrm{~min}$ apart from each other. At 105 min after the first biopsy, a second muscle biopsy was taken marking the end of the baseline period. However, under this circumstance, the biopsy needle was inclined 
at a different angle so that the second biopsy was taken approximately $\sim 5 \mathrm{~cm}$ apart from the first.

Following the second biopsy, the subjects were escorted to the Cybex leg extension machine. There the subjects performed eight sets of ten repetitions of two-legged extension exercises set to $70 \%$ of their 1RM. The rest period between sets was 3 min. Blood samples were collected immediately after the third, sixth, and eighth sets. Following the last blood collection, the subjects were then transported back to their hospital bed for the remainder of the study. Blood samples were taken every 15 min during the first hour of recovery from exercise. At $1 \mathrm{~h}$ postexercise, a third muscle biopsy was obtained angling the needle once again so that the muscle biopsy was sampled $\sim 5 \mathrm{~cm}$ from the second biopsy.

Immediately after the third biopsy, subjects ingested a solution $(500 \mathrm{ml})$ that contained $20 \mathrm{~g}$ of EAAs. This EAA dosage is consistent with our previous publications $(14,18)$ and is optimal to stimulate protein synthesis and mTOR signaling. The composition of the EAA mixture was the following: histidine (8\%), isoleucine (8\%), leucine (35\%), lysine (12\%), methionine (3\%), phenylalanine (14\%), threonine (10\%), and valine (10\%) (Ajinomoto/Sigma Aldrich, Raleigh, NC). Therefore, our EAA mixture was highly enriched in leucine. To minimize changes in blood phenylalanine enrichment we added a small amount of ${ }_{\mathrm{L}}-\left[\mathrm{ring}-{ }^{2} \mathrm{H}_{5}\right.$ ] phenylalanine to the EAA mixture to increase the mixtures' ${ }_{L}-\left[\right.$ ring- ${ }^{2} \mathrm{H}_{5}$ ] phenylalanine enrichment to the predicted blood ${ }_{\mathrm{L}}-\left[\right.$ ring- $\left.{ }^{2} \mathrm{H}_{5}\right]$ phenylalanine enrichment (i.e., 6.5\%). Blood samples were collected every 15 min during the $2 \mathrm{~h}$ following the amino acid drink. At the end of the third hour postexercise, a fourth muscle biopsy was collected from a new incision site $\sim 7 \mathrm{~cm}$ proximal to the first incision. Blood samples were drawn every $30 \mathrm{~min}$ for the next $3 \mathrm{~h}$. A final biopsy was collected $6 \mathrm{~h}$ postexercise from the second incision site with the biopsy needle facing a new direction in the muscle than previously, $\sim 5 \mathrm{~cm}$ from the fourth biopsy.

\section{RNA isolation}

Total RNA was isolated by homogenizing 30-40 mg tissue with a homogenizing dispenser (T10 Basic Ultra Turrax, IKA, Wilmington, NC) in a solution containing $1.0 \mathrm{ml}$ of TRI reagent and $4 \mu \mathrm{l}$ of polyacryl carrier (Molecular Research Center, Cincinnati, OH). The RNA was separated into an aqueous phase with $0.2 \mathrm{ml}$ of chloroform and precipitated from the aqueous phase with $0.50 \mathrm{ml}$ of isopropanol. Extracted RNA was washed with $1 \mathrm{ml}$ of $75 \%$ ethanol, dried, and then suspended in a known amount $(1.5 \mu \mathrm{l} / \mathrm{mg}$ tissue $)$ of nuclease-free water. RNA was quantified spectrophotometrically (Bio-Rad, SmartSpec, Hercules, CA) at a wavelength of $260 \mathrm{~nm}$. RNA concentration was calculated on the basis of total RNA yield. RNA quality was assessed by RNA agarose gel electrophoresis followed by visualization of the 18 and 28S ribosomal RNA bands under ultraviolet light. Total RNA was used to calculate the RNA-to protein ratio, an index of ribosomal capacity.

\section{Muscle fractional synthetic rate}

Muscle tissue samples were ground, and intracellular free amino acids and muscle proteins were extracted as previously described (13). Blood and muscle intracellular free concentration of leucine and phenylalanine and the enrichment of phenylalanine were determined by gas chromatography-mass spectrometry (GC-MS, 6890 Plus GC, 5973N MSD, 7683 autosampler, Agilent Technologies, Palo Alto, CA) using appropriate internal standards (60). Mixed muscle protein-bound phenylalanine enrichment was analyzed by GC-MS after protein hydrolysis and amino acid extraction (13), using the external standard curve approach (10). We calculated the fractional synthetic rate (FSR) of mixed muscle proteins by measuring the incorporation rate of the phenylalanine tracer into the proteins $\left(\Delta \mathrm{E}_{\mathrm{p}} / t\right)$ and using the precursor-product model to calculate the synthesis rate: 


$$
\mathrm{FSR}=\left(\Delta \mathrm{E}_{\mathrm{p}} / t\right) /\left[\mathrm{E}_{\mathrm{M}(1)}+\mathrm{E}_{\mathrm{M}(2)} / 2\right] \cdot 60 \cdot 100
$$

where $\Delta \mathrm{E}_{\mathrm{p}}$ is the increment in protein-bound phenylalanine enrichment between two sequential biopsies, $t$ is the time between the two sequential biopsies, and $\mathrm{E}_{\mathrm{M}(1)}$ and $\mathrm{E}_{\mathrm{M}(2)}$ are the phenylalanine enrichments in the free intracellular pool in the two sequential biopsies. Data are expressed as percent per hour.

\section{Immunoblot analysis}

Details to immunoblotting can be found elsewhere (13). Briefly, $70 \mathrm{mg}$ of frozen tissue was homogenized and centrifuged for $10 \mathrm{~min}$ at $4{ }^{\circ} \mathrm{C}$, and supernatant was collected. Total protein concentrations were determined by the Bradford assay and quantified using the Smartspec Plus spectrophotometer (BioRad). The supernatant was diluted (1:1) in a sample buffer mixture containing $125 \mathrm{mM}$ Tris, pH 6.8; 25\% glycerol; $2.5 \%$ SDS $2.5 \% \beta$-mercaptoethanol, and $0.002 \%$ bromophenol blue, then boiled for $3 \mathrm{~min}$ at $100^{\circ} \mathrm{C}$. However, homogenate aliquots used to detect 4E-BP1 were initially boiled at $100^{\circ} \mathrm{C}$ for $10 \mathrm{~min}$ and spun for $30 \mathrm{~min}$ at 6,000 $g$ before the supernatants were combined with the sample buffer. Equal amounts of total protein were loaded into each lane and the samples were separated by electrophoresis ( $150 \mathrm{~V}$ for 60 min) on a 7.5 or $15 \%$ polyacrylamide gel as determined by the size of the target protein (Criterion, Bio-Rad). Each sample was loaded in duplicate and each gel contained an internal loading control (rodent skeletal muscle) and molecular weight ladder (Precision Plus). Following electrophoresis, protein was transferred to a polyvinylidene difluoride membrane (Bio-Rad) at $50 \mathrm{~V}$ for $60 \mathrm{~min}$. Blots were incubated in primary antibody overnight at $4^{\circ} \mathrm{C}$ (antibody concentrations are described below). The next morning, blots were incubated in secondary antibody for $1 \mathrm{~h}$ at room temperature. Chemiluminescent solution (ECL plus, Amersham BioSciences, Piscataway, NJ) was applied to each blot. After a 5-min incubation, optical density measurements were obtained with a phosphoimager (ChemiDoc, Bio-Rad) and densitometric analysis was performed with Quantity One 4.5.2 software (Bio-Rad). Membranes containing phospho-detected proteins were stripped of primary and secondary antibodies by use of Restore Western blot stripping buffer (Pierce Biotechnology). After incubation in stripping buffer, membranes were reprobed for total protein with specific antibody of interest. Phospho and total density values were normalized to an internal loading control (which was loaded on each respective blot) and the phospho-to-total protein ratios were determined. Immunoblot data was expressed as normalized phospho divided by normalized total protein (phospho/total). However, AMPK $\alpha$ phosphorylation was expressed as phospho normalized to internal loading control because AMPK is a heterotrimeric protein with differences in catalytic subunit activation due to exercise. AMPK $\alpha 1$ and $\alpha 2$ activity can both be altered with muscle contraction under certain circumstances (49); however, we chose to measure AMPK $\alpha 2$ phosphorylation on the basis of previous work showing that this isoform is predominantly activated during moderate to high-intensity muscle contraction in humans $(4,59)$.

\section{Hormones and glucose/lactate}

Serum concentrations of cortisol, growth hormone, insulin, and total testosterone were determined by chemiluminescent enzyme immunoassay using the Immulite 2000. Plasma glucose and lactate concentration was measured using an automated glucose and lactate analyzer (YSI, Yellow Springs, OH). 


\section{Antibodies}

The phospho primary antibodies used were purchased from Cell Signaling (Beverly, MA) unless otherwise noted: phospho-Akt (Ser473; 1:1,000), phospho-AMPK $\alpha$ (Thr172; 1:1,000), phosphomTOR (Ser2448; 1:1,000), phospho-p70 S6K1 (Thr389; 1:500), phospho-4E-BP1 (Thr37/46; 1:1,000), phospho-eukaryotic elongation factor 2 (eEF2) (Thr56; 1:1,000), phospho-glycogen synthase kinase $\beta$ (GSK3 $\beta$ ) (Ser9; 1:1,000), phospho-eukaryotic initiation factor $\alpha$ (eIF2 $\alpha$ ) (Ser52; 1:1,000; Invitrogen, Carlsbad, CA), phospho-ERK1/2 (Thr202/ Tyr204; 1:1,000) and phospho-MNK1 (Thr197; 1:1,000). Total protein for each of these molecules [including total neuronal nitric oxide synthase (nNOS)] was purchased from Cell Signaling and detected by using an antibody dilution of 1:1,000. Anti-rabbit IgG horseradish peroxidase-conjugated secondary antibody was purchased from Amersham Bioscience $(1: 2,000)$.

\section{Statistical analysis}

Data are reported as means \pm SE. Betweenand within-group differences were tested by a repeated-measures ANOVA. Simple contrasts were used to assess main and interaction effects between particular time points. Post hoc paired $t$-tests were done to identify specific intragroup differences when the ANOVA models produced significant main or interaction effects. Alpha was set to $<0.05$. All analyses were done with SPSS v14 software.

\section{RESULTS}

\section{Baseline measurements}

As expected, the ages of the two groups were significantly different from each other $(P<0.05$; Table 1). In addition, young subjects had a trend for higher leg lean mass (Leg LM) $(P=0.087)$ compared with the old. However, when the 1RM data were arranged to account for Leg LM [an indirect measure of muscle quality; Relative 1RM (1RM/Leg LM)] these strength differences were minimized $(P>0.05)$. Young subjects had a significantly greater absolute $1 \mathrm{RM}$ and lifted a greater average weight per set $(P<0.05)$. Total work per set in young subjects was greater than the old subjects $(2.54 \pm 0.01$ vs. $1.68 \pm 0.01 \mathrm{~kJ}$, respectively $)(P<0.05)$.

To further determine skeletal muscle growth regulation differences between young and old, we identified the total protein expression of nNOS. nNOS appears to be a regulator of force production and therefore has been shown to be less in rats undergoing atrophy (hindlimb suspension) (47). Our data indicate that there were no differences in total nNOS at baseline (young: $0.85 \pm 0.14$ and old: $0.77 \pm 0.20$ arbitrary units) or at $6 \mathrm{~h}$ postexercise between young and old subjects (young: $0.77 \pm 0.13$ and old: $0.57 \pm 0.11$ arbitrary units) $(P>0.05)$.

\section{Serum hormones and blood glucose/lactate}

Cortisol levels were significantly reduced in the young at 4 and $5 \mathrm{~h}$ postexercise compared with baseline $(P<0.05$; Table 2$)$. Insulin was significantly increased immediately after exercise and at 1,2 , and $3 \mathrm{~h}$ postexercise in the young compared with baseline $(P<0.05)$. Testosterone was significantly increased immediately after exercise but was lower at $3 \mathrm{~h}$ postexercise in the young compared with baseline $(P<0.05)$. There were no changes in old for cortisol, insulin, or testosterone compared with baseline over the course of study $(P>0.05)$. Blood glucose was significantly lower during 2- $6 \mathrm{~h}$ postexercise for young and old subjects compared with baseline $(P<0.05)$. Blood lactate was significantly elevated for young and old subjects during and $1 \mathrm{~h}$ after exercise compared with baseline. Blood lactate was higher during exercise in the young compared with old $(P<0.05)$. Blood lactate levels significantly decreased below baseline levels between $4-6 \mathrm{~h}$ postexercise in the old and by $6 \mathrm{~h}$ postexercise in the young $(P$ $<0.05)$. 


\section{Phenylalanine and leucine concentrations}

Blood phenylalanine and leucine concentrations were significantly elevated in the young and old subjects at 2, 3, and $4 \mathrm{~h}$ post exercise compared with baseline $(P<0.05$; Table 3$)$; however, the increase was greater in the old than young at $4 \mathrm{~h}$ postexercise $(P<0.05)$. Blood phenylalanine and leucine concentrations continued to remain elevated in the old at 5 and $6 \mathrm{~h}$ postexercise $(P<0.05)$ whereas blood phenylalanine values returned to baseline in the young. Muscle intracellular concentrations of phenylalanine and leucine were significantly elevated in the young and old at $3 \mathrm{~h}$ postexercise compared with baseline $(P<0.05)$. Muscle intracellular concentrations of leucine continued to stay elevated in the young and old at $6 \mathrm{~h}$ postexercise compared with baseline $(P<0.05)$.

\section{Muscle protein synthesis}

Mixed muscle protein synthesis (i.e., FSR) was significantly elevated in the young 1-3 $\mathrm{h}$ postexercise compared with baseline and was significantly higher than the old (Fig. $2 A ; P<$ $0.05)$. Muscle protein synthesis at 3- $6 \mathrm{~h}$ postexercise was significantly elevated to a similar extent in both age groups compared with baseline (Fig. $2 A ; P<0.05$ ). Muscle protein synthesis over the entire 5-h post-EAA ingestion period ( $1-6 \mathrm{~h}$ postexercise) was increased above baseline and similar between young and old (Fig. $2 B ; P<0.05$ ).

\section{Upstream mTOR regulators}

The phosphorylation status of Akt at Ser473 was significantly increased for the young compared with baseline at $3 \mathrm{~h}$ postexercise $(P<0.05)$ whereas there was no difference in the old (Fig. $3 A$ ). At 1 and $3 \mathrm{~h}$ postexercise, AMPK $\alpha$ phosphorylation at Thr 172 was higher in the old at 1 and $3 \mathrm{~h}$ (Fig. $3 B ; P<0.05$ ), and this increase was significantly greater than the young at $3 \mathrm{~h}$ postexercise $(P<0.05)$.

\section{mTOR signaling}

mTOR phosphorylation at Ser2448 was increased to a similar extent at all time points compared with baseline for both young and old subjects (Fig. 4A; $P<0.05$ ). S6K1 phosphorylation at Thr389 was significantly increased at all time points postexercise compared with baseline for both age groups although there was a tendency $(P=0.07)$ for S6K1 phosphorylation to be increased in the young at $6 \mathrm{~h}$ postexercise (Fig. $4 B ; P<0.05$ ). However, phospho-S6K1 tended to be higher in young than the old subjects at $1 \mathrm{~h}$ postexercise prior to EAA ingestion $(P=$ 0.09). 4E-BP1 phosphorylation at Thr $37 / 46$ was significantly increased at $3 \mathrm{~h}$ postexercise for both the young and old subjects but only remained elevated at $6 \mathrm{~h}$ postexercise in the young (Fig. $4 C ; P<0.05$ ). eEF2 phosphorylation at Thr56 tended to be lower at $1 \mathrm{~h}$ postexercise in both age groups $(P=0.07)$ and was significantly lower at 3 and $6 \mathrm{~h}$ postexercise for young and old subjects (Fig. $4 D ; P<0.05$ ).

\section{Eukaryotic initiation factor $2 \mathrm{~B}$ regulators}

GSK3 $\beta$ phosphorylation at Ser9 did not change in either group postexercise, although it was slightly lower in the young at $6 \mathrm{~h}$ postexercise compared with baseline (Fig. $5 A ; P<0.05$ ). eIF2 $\alpha$ phosphorylation was significantly lower at $1 \mathrm{~h}$ postexercise in the young compared with baseline $(P<0.05)$. but unchanged in the old (Fig. 5B).

\section{ERK signaling}

ERK1/2 phosphorylation was significantly elevated only in the young at $1 \mathrm{~h}$ postexercise $(P$ $<0.05$ )., which tended to be greater than the old (Fig. $6 A ; P=0.07$ ). MNK1 phosphorylation was significantly elevated at $1 \mathrm{~h}$ postexercise only in the young, and these values were 
significantly greater than the old (Fig. $6 B ; P<0.05$ ). Furthermore, MNK1 phosphorylation was higher in young compared with the old at $3 \mathrm{~h}$ postexercise $(P<0.05)$.

\section{DISCUSSION}

The primary finding from this study was that muscle protein synthesis following resistance exercise and EAA ingestion was delayed in skeletal muscle of elderly men compared with young. This delayed activation may have been due to the inability of old skeletal muscle to adequately activate both ERK and mTOR signaling following resistance exercise. Specifically, resistance exercise increased ERK1/2 and MNK1 phosphorylation at $1 \mathrm{~h}$ postexercise only in the young subjects. In addition, S6K1 phosphorylation (a downstream effector of mTOR) tended to be higher and eIF $2 \alpha$ phosphorylation was reduced at $1 \mathrm{~h}$ postexercise in young muscle, indicating that the ability of resistance exercise to adequately stimulate pathways controlling translation initiation is greater in young vs. old human skeletal muscle.

Furthermore, at 1 and $3 \mathrm{~h}$ postexercise, AMPK $\alpha$ phosphorylation (a negative regulator of mTOR signaling) was greater in old skeletal muscle compared with young. At $1 \mathrm{~h}$ postexercise all subjects ingested $20 \mathrm{~g}$ of EAAs, and the rate of muscle protein synthesis between 1-3 $\mathrm{h}$ postexercise was elevated only in the young. Contrary to the reduced signaling immediately following exercise in the old individuals, muscle mTOR signaling (mTOR, S6K1, 4E-BP1, eEF2) was similar between young and old subjects at $3 \mathrm{~h}$ postexercise; however, AMPK phosphorylation remained elevated in the old group and MNK1 phosphorylation was blunted compared with the young at this same point. Eventually muscle protein synthesis was stimulated in the skeletal muscle of the old individuals (3- $6 \mathrm{~h}$ postexercise) to the same extent as seen in young muscle. These data imply that reduced and enhanced signaling from MNK1 and AMPK $\alpha$, respectively, may be potential mechanisms for the delayed exercise and nutrient response in old human skeletal muscle.

Several reports have identified skeletal muscle cell signaling and protein synthesis inconsistencies between young and old individuals after an acute bout of resistance exercise $(28,29,41)$. For example, we have previously shown that muscle protein synthesis was unchanged in the old after a single bout of resistance exercise (44) as opposed to young subjects (13). We further support these findings by indicating that key regulators of muscle protein synthesis are differentially regulated in skeletal muscle after resistance exercise between young and old subjects. We report that young individuals respond to resistance exercise more robustly as indicated by higher phosphorylation status of S6K1 (Fig. 4B), ERK1/2 and MNK1 (Fig. 6, $A$ and $B$ ) compared with old individuals $1 \mathrm{~h}$ after resistance exercise. This finding is supported by data indicating that S6K1 and ERK1/2 phosphorylation were unchanged and/or blunted in the plantaris and tibialis muscle after electrical stimulation-induced muscle contraction in older rats compared with young (39). In addition, we show for the first time a significant reduction in the phosphorylation of eIF2 $\alpha 1 \mathrm{~h}$ after resistance exercise only in young muscle (Fig. $5 B$ ). Phosphorylation of eIF2 $\alpha$ inhibits the ability of eukaryotic initiation factor 2B (eIF2B) to properly exchange GTP for GDP, thus negatively regulating protein synthesis (12). Although we found that GSK3 $\beta$ phosphorylation was unchanged $1 \mathrm{~h}$ after resistance exercise (Fig. $5 A$ ), as also recently shown by Blomstrand et al. (5), a decrease in eIF2 $\alpha$ phosphorylation may be the necessary stimulus to increase activity levels of eIF2B above baseline and thus further promote protein synthesis. Our findings are different from a previous study in rats in which eIF2 $\alpha$ phosphorylation was unchanged after resistance exercise (8). However, differences may be a result of species used (rodents vs. humans) and the type and amount of stress placed on the muscle. In any event, our data indicate that anabolic signaling in skeletal muscle is more pronounced in young subjects compared with the old immediately following a bout of resistance exercise. 
EAA ingestion following resistance exercise has been shown to enhance muscle protein synthesis compared with resistance exercise without nutrient ingestion $(3,9,21,30,31,40,48$, 56). Likewise we and others have demonstrated that the combination of resistance exercise followed by ingestion of EAA further augments protein synthesis concurrently with mTOR signaling to a greater degree than resistance exercise alone $(14,27)$. In contrast to our original hypothesis, we show that mixed-muscle protein synthesis was not increased in response to EAA ingestion during the 1-3 $\mathrm{h}$ following resistance exercise in old individuals whereas the young individuals demonstrated a $145 \%$ increase in muscle protein synthesis $1-3 \mathrm{~h}$ after exercise (Fig. 2A). This outcome occurred even in the presence of a similar increase in mTOR signaling (mTOR, S6K1, 4E-BP1, eEF2) between the age groups at $3 \mathrm{~h}$ postexercise (Fig. 4). However, muscle protein synthesis during 3-6 $\mathrm{h}$ postexercise was similar and significantly elevated compared with baseline in both young and old men (Fig. 2A). This end point supports the findings of Koopman et al. (30), who identified that young and old men had similar muscle protein synthesis rates over a 6-h period following activities of daily living and protein and carbohydrate ingestion. However, these authors did not measure protein synthesis rates at $3 \mathrm{~h}$ postactivity and therefore any delayed response would have been undetected. Furthermore, we indicate that muscle protein synthesis over the initial $6 \mathrm{~h}$ postexercise time course was similar between young and old men (Fig. $2 B$ ); however, we are unsure whether this trend would exist beyond $6 \mathrm{~h}$ postexercise. Nonetheless, the data in the present study show that the stimulation of muscle protein synthesis immediately following resistance exercise and EAA ingestion in old men is delayed but is restored by $6 \mathrm{~h}$.

The explanation for delayed muscle protein synthesis in the older individuals is unclear. It appears that delivery of amino acids to the muscle was not a limiting factor because muscle intracellular concentrations of leucine and phenylalanine were similar at $3 \mathrm{~h}$ postexercise between the age groups (Table 3). However, Akt phosphorylation was higher in the young and unchanged in the old at $3 \mathrm{~h}$ postexercise compared with baseline (Fig. 3A). Most likely the elevated Akt phosphorylation in the young occurred because of increased insulin release (Table 2), although muscle contraction has also been shown to activate Akt independent of systemic factors such as insulin (42). Amino acid stimulation of insulin secretion in old individuals was reduced compared with the young (38) and may have played a role in limiting anabolic signaling through this pathway. Regardless, the increase in Akt phosphorylation in the young was not sufficient to alter GSK3 $\beta$ phosphorylation (Fig. 5A).

The ERK pathway appears to be a potent control point for protein synthesis $(17,39,57,58)$ and operates independently of mTOR signaling through enhanced phosphorylation of the eIF4E complex. We report that ERK1/2 phosphorylation at $3 \mathrm{~h}$ postexercise was unchanged in both young and old skeletal muscle (Fig. 6A); however, MNK1 phosphorylation remained elevated and was higher in the young than the old at this time point. Our data are supported by other reports indicating that MAPK signaling has been shown to be unresponsive after resistance exercise in aged rat (39) and human (57) skeletal muscle. Therefore, it appears that dual activation of both ERK and mTOR signaling is required for stimulating muscle protein synthesis in the early recovery period (i.e., $1-3 \mathrm{~h}$ postexercise).

In general, old skeletal muscle displays atrophy of type II fibers (36) and the number of motor units decrease with age (50). Therefore, it cannot be ruled out that differences between the age groups in our study are a result of the old subjects generating less exercise tension than their younger counterparts despite exercising at the same relative exercise intensity (70\% 1RM). In support of differences in muscle recruitment, we report that the young subjects produced larger amounts of lactate compared with the old (Table 2). Lower lactate levels in old subjects after resistance exercise have been reported previously (33). Furthermore, MAPK signaling appears to be exercise intensity and type II fiber dependent $(45,55)$. Therefore, it is likely that differences in muscle fiber-type composition and mass may explain the inability of older 
individuals to activate ERK signaling following a bout of resistance exercise (when performed at the same relative intensity compared with the young).

Although the absolute workload was less in the old subjects, apparently muscle contraction was of sufficient magnitude to induce a significant cellular stress response (i.e., increased AMPK $\alpha$ phosphorylation) during the early postexercise recovery period. We report that AMPK $\alpha$ phosphorylation at Thr172 (Fig. 3B) was elevated only in old muscle at 1 and $3 \mathrm{~h}$ postexercise. In support of our data, Thomson and Gordon (46) have demonstrated that AMPK $\alpha$ phosphorylation was higher at baseline and after $1 \mathrm{wk}$ of synergistic ablation in older rat fast-twitch skeletal muscle compared with young rats. Furthermore, eIF $2 \alpha$ phosphorylation increases with hypoxia and other measures of cellular stress. We found that eIF2 $\alpha$ phosphorylation at Ser52 was reduced in young muscle (indicative of increased protein synthesis) but unchanged in old skeletal muscle at $1 \mathrm{~h}$ postexercise (Fig. $5 B$ ). Therefore, the contraction-induced cellular stress following resistance exercise may also be playing a role in delaying the increase in muscle protein synthesis.

In summary, muscle protein synthesis following resistance exercise and EAA ingestion increased in the young subjects at 1-3 and 3-6 $\mathrm{h}$ postexercise but only during the 3-6 $\mathrm{h}$ postexercise period in the old men. Skeletal muscle ERK and mTOR signaling both increased $1 \mathrm{~h}$ following resistance exercise in the young; however, ERK signaling was unaffected in the old men. Differences in muscle protein synthesis at $3 \mathrm{~h}$ postexercise in young and old subjects were independent of mTOR and Akt/GSK3 $\beta$ signaling pathways but appear to be dependent on ERK and AMPK signaling. We conclude that the stimulation of muscle protein synthesis in old men is delayed following resistance exercise and EAA ingestion. The mechanism(s) responsible for the delay in protein synthesis may be due to an inability of the old men to activate both ERK and mTOR signaling concurrently following resistance exercise.

Furthermore, old skeletal muscle appears to exhibit a greater cellular energetic stress response as shown by the higher phosphorylation of AMPK $\alpha$ during postexercise recovery. An extended time course for the protein anabolic response following resistance exercise and EAA ingestion is needed. In addition, future studies are needed to determine whether resistance exercise training (in combination with leucine-enriched EAA ingestion following each training session) can restore the muscle growth response in old individuals.

\section{ACKNOWLEDGMENTS}

We thank the GCRC nursing and Sealy Center on Aging staff for valuable efforts in recruiting subjects and in assisting with the clinical portion of this study.

GRANTS This study was supported by National Institute of Arthritis and Musculo-skeletal and Skin Diseases Grant no. R01 AR049877 and National Institute on Aging Grants P30 AG024832 and R01 AG018311.

\section{REFERENCES}

1. Aniansson A, Grimby G, Rundgren A. Isometric and isokinetic quad-riceps muscle strength in 70year-old men and women. Scand J Rehabil Med 1980;12:161-168. [PubMed: 7268324]

2. Baumgartner RN, Koehler KM, Gallagher D, Romero L, Heymsfield SB, Ross RR, Garry PJ, Lindeman RD. Epidemiology of sarcopenia among the elderly in New Mexico. Am J Epidemiol 1998;147:755763. [PubMed: 9554417]

3. Biolo G, Tipton KD, Klein S, Wolfe RR. An abundant supply of amino acids enhances the metabolic effect of exercise on muscle protein. Am J Physiol Endocrinol Metab 1997;273:E122-E129.

4. Birk JB, Wojtaszewski JF. Predominant alpha2/beta2/gamma3 AMPK activation during exercise in human skeletal muscle. J Physiol 2006;577:1021-1032. [PubMed: 17038425]

5. Blomstrand E, Eliasson J, Karlsson HK, Kohnke R. Branched-chain amino acids activate key enzymes in protein synthesis after physical exercise. J Nutr 2006;136:269S-273S. [PubMed: 16365096] 
6. Bodine SC, Stitt TN, Gonzalez M, Kline WO, Stover GL, Bauerlein R, Zlotchenko E, Scrimgeour A, Lawrence JC, Glass DJ, Yancopoulos GD. Akt/mTOR pathway is a crucial regulator of skeletal muscle hyper-trophy and can prevent muscle atrophy in vivo. Nat Cell Biol 2001;3:1014-1019. [PubMed: 11715023]

7. Bolster DR, Crozier SJ, Kimball SR, Jefferson LS. AMP-activated protein kinase suppresses protein synthesis in rat skeletal muscle through down-regulated mammalian target of rapamycin (mTOR) signaling. J Biol Chem 2002;277:23977-23980. [PubMed: 11997383]

8. Bolster DR, Kubica N, Crozier SJ, Williamson DL, Farrell PA, Kimball SR, Jefferson LS. Immediate response of mammalian target of rapamycin (mTOR)-mediated signalling following acute resistance exercise in rat skeletal muscle. J Physiol 2003;553:213-220. [PubMed: 12937293]

9. Borsheim E, Tipton KD, Wolf SE, Wolfe RR. Essential amino acids and muscle protein recovery from resistance exercise. Am J Physiol Endocrinol Metab 2002;283:E648-E657. [PubMed: 12217881]

10. Calder AG, Anderson SE, Grant I, McNurlan MA, Garlick PJ. The determination of low d5phenylalanine enrichment (0.002-009 atom percent excess), after conversion to phenylethylamine, in relation to protein turnover studies by gas chromatography/electron ionization mass spectrometry. Rapid Commun Mass Spectrom 1992;6:421-424. [PubMed: 1638043]

11. Cuthbertson D, Smith K, Babraj J, Leese G, Waddell T, Atherton P, Wackerhage H, Taylor PM, Rennie MJ. Anabolic signaling deficits underlie amino acid resistance of wasting, aging muscle. FASEB J 2005;19:422-424. [PubMed: 15596483]

12. De Haro C, Mendez R, Santoyo J. The eIF-2alpha kinases and the control of protein synthesis. FASEB J 1996;10:1378-1387. [PubMed: 8903508]

13. Dreyer HC, Fujita S, Cadenas JG, Chinkes DL, Volpi E, Rasmussen BB. Resistance exercise increases AMPK activity and reduces 4E-BP1 phosphorylation and protein synthesis in human skeletal muscle. J Physiol 2006;576:613-624. [PubMed: 16873412]

14. Dreyer HC, Drummond MJ, Pennings B, Fujita S, Glynn EL, Chinkes DL, Dhanani S, Volpi E, Rasmussen BB. Leucine-enriched essential amino acid and carbohydrate ingestion following resistance exercise enhances mTOR signaling and protein synthesis in human muscle. Am J Physiol Endocrinol Metab 2008;294:E392-E400. [PubMed: 18056791]

15. Esmarck B, Andersen JL, Olsen S, Richter EA, Mizuno M, Kjaer M. Timing of postexercise protein intake is important for muscle hypertrophy with resistance training in elderly humans. J Physiol 2001;535:301-311. [PubMed: 11507179]

16. Ferrucci L, Izmirlian G, Leveille S, Phillips CL, Corti MC, Brock DB, Guralnik JM. Smoking, physical activity, and active life expectancy. Am J Epidemiol 1999;149:645-653. [PubMed: 10192312]

17. Fluckey JD, Knox M, Smith L, Dupont-Versteegden EE, Gaddy D, Tesch PA, Peterson CA. Insulinfacilitated increase of muscle protein synthesis after resistance exercise involves a MAP kinase pathway. Am J Physiol Endocrinol Metab 2006;290:E1205-E1211. [PubMed: 16418205]

18. Fujita S, Dreyer HC, Drummond MJ, Glynn EL, Cadenas JG, Yoshizawa F, Volpi E, Rasmussen BB. Nutrient signalling in the regulation of human muscle protein synthesis. J Physiol 2007;582:813823. [PubMed: 17478528]

19. Funai K, Parkington JD, Carambula S, Fielding RA. Age-associated decrease in contraction-induced activation of downstream targets of Akt/mTor signaling in skeletal muscle. Am J Physiol Regul Integr Comp Physiol 2006;290:R1080-R1086. [PubMed: 16306159]

20. Hartman JW, Moore DR, Phillips SM. Resistance training reduces whole-body protein turnover and improves net protein retention in untrained young males. Appl Physiol Nutr Metab 2006;31:557564. [PubMed: 17111010]

21. Hartman JW, Tang JE, Wilkinson SB, Tarnopolsky MA, Lawrence RL, Fullerton AV, Phillips SM. Consumption of fat-free fluid milk after resistance exercise promotes greater lean mass accretion than does consumption of soy or carbohydrate in young, novice, male weightlifters. Am J Clin Nutr 2007;86:373-381. [PubMed: 17684208]

22. Holloszy JO. The biology of aging. Mayo Clin Proc 2000;75(Suppl):S3-S8. [PubMed: 10959208] discussion S8-S9 
23. Hornberger TA, Mateja RD, Chin ER, Andrews JL, Esser KA. Aging does not alter the mechanosensitivity of the p38, p70S6k, and JNK2 signaling pathways in skeletal muscle. J Appl Physiol 2005;98:1562-1566. [PubMed: 15361519]

24. Iannuzzi-Sucich M, Prestwood KM, Kenny AM. Prevalence of sarcopenia and predictors of skeletal muscle mass in healthy, older men and women. J Gerontol A Biol Sci Med Sci 2002;57:M772-M777. [PubMed: 12456735]

25. Inoki K, Zhu T, Guan KL. TSC2 mediates cellular energy response to control cell growth and survival. Cell 2003;115:577-590. [PubMed: 14651849]

26. Janssen I, Baumgartner RN, Ross R, Rosenberg IH, Roubenoff R. Skeletal muscle cutpoints associated with elevated physical disability risk in older men and women. Am J Epidemiol 2004;159:413-421. [PubMed: 14769646]

27. Karlsson HK, Nilsson PA, Nilsson J, Chibalin AV, Zierath JR, Blom-strand E. Branched-chain amino acids increase p70S6k phosphorylation in human skeletal muscle after resistance exercise. Am J Physiol Endocrinol Metab 2004;287:E1-E7. [PubMed: 14998784]

28. Kim JS, Cross JM, Bamman MM. Impact of resistance loading on myostatin expression and cell cycle regulation in young and older men and women. Am J Physiol Endocrinol Metab 2005;288:E1110E1119. [PubMed: 15644458]

29. Kim JS, Kosek DJ, Petrella JK, Cross JM, Bamman MM. Resting and load-induced levels of myogenic gene transcripts differ between older adults with demonstrable sarcopenia and young men and women. J Appl Physiol 2005;99:2149-2158. [PubMed: 16051712]

30. Koopman R, Verdijk L, Manders RJ, Gijsen AP, Gorselink M, Pijpers E, Wagenmakers AJ, van Loon LJ. Co-ingestion of protein and leucine stimulates muscle protein synthesis rates to the same extent in young and elderly lean men. Am J Clin Nutr 2006;84:623-632. [PubMed: 16960178]

31. Koopman R, Beelen M, Stellingwerff T, Pennings B, Saris WH, Kies AK, Kuipers H, van Loon LJ. Coingestion of carbohydrate with protein does not further augment postexercise muscle protein synthesis. Am J Physiol Endocrinol Metab 2007;293:E833-E842. [PubMed: 17609259]

32. Kosek DJ, Kim JS, Petrella JK, Cross JM, Bamman MM. Efficacy of 3 days/wk resistance training on myofiber hypertrophy and myogenic mechanisms in young vs. older adults. J Appl Physiol 2006;101:531-544. [PubMed: 16614355]

33. Kraemer WJ, Hakkinen K, Newton RU, McCormick M, Nindl BC, Volek JS, Gotshalk LA, Fleck SJ, Campbell WW, Gordon SE, Farrell PA, Evans WJ. Acute hormonal responses to heavy resistance exercise in younger and older men. Eur J Appl Physiol 1998;77:206-211.

34. Kubica N, Bolster DR, Farrell PA, Kimball SR, Jefferson LS. Resistance exercise increases muscle protein synthesis and translation of eukaryotic initiation factor 2Bepsilon mRNA in a mammalian target of rapamycin-dependent manner. J Biol Chem 2005;280:7570-7580. [PubMed: 15591312]

35. Leveille SG, Guralnik JM, Ferrucci L, Langlois JA. Aging successfully until death in old age: opportunities for increasing active life expectancy. Am J Epidemiol 1999;149:654-664. [PubMed: 10192313]

36. Lexell J, Taylor CC, Sjostrom M. What is the cause of the ageing atrophy? Total number, size and proportion of different fiber types studied in whole vastus lateralis muscle from 15- to 83-year-old men. J Neurol Sci 1988;84:275-294. [PubMed: 3379447]

37. Melton LJ 3rd, Khosla S, Riggs BL. Epidemiology of sarcopenia. Mayo Clin Proc 2000;75 (Suppl):S10-S12. [PubMed: 10959209]discussion S12-S13

38. Paddon-Jones D, Sheffield-Moore M, Zhang XJ, Volpi E, Wolf SE, Aarsland A, Ferrando AA, Wolfe RR. Amino acid ingestion improves muscle protein synthesis in the young and elderly. Am J Physiol Endocrinol Metab 2004;286:E321-E328. [PubMed: 14583440]

39. Parkington JD, LeBrasseur NK, Siebert AP, Fielding RA. Contraction-mediated mTOR, p70S6k, and ERK1/2 phosphorylation in aged skeletal muscle. J Appl Physiol 2004;97:243-248. [PubMed: 15033970]

40. Rasmussen BB, Tipton KD, Miller SL, Wolf SE, Wolfe RR. An oral essential amino acidcarbohydrate supplement enhances muscle protein anabolism after resistance exercise. J Appl Physiol 2000;88:386-392. [PubMed: 10658002] 
41. Raue U, Slivka D, Jemiolo B, Hollon C, Trappe S. Myogenic gene expression at rest and after a bout of resistance exercise in young (18-30 yr) and old (80-89 yr) women. J Appl Physiol 2006;101:5359. [PubMed: 16601301]

42. Sakamoto K, Hirshman MF, Aschenbach WG, Goodyear LJ. Contraction regulation of Akt in rat skeletal muscle. J Biol Chem 2002;277:11910-11917. [PubMed: 11809761]

43. Sayer AA, Syddall HE, Martin HJ, Dennison EM, Anderson FH, Cooper C. Falls, sarcopenia, and growth in early life: findings from the Hertfordshire cohort study. Am J Epidemiol 2006;164:665671. [PubMed: 16905644]

44. Sheffield-Moore M, Paddon-Jones D, Sanford AP, Rosenblatt JI, Matlock AG, Cree MG, Wolfe RR. Mixed muscle and hepatic derived plasma protein metabolism is differentially regulated in older and younger men following resistance exercise. Am J Physiol Endocrinol Metab 2005;288:E922-E929. [PubMed: 15644460]

45. Shi H, Zeng C, Ricome A, Hannon KM, Grant AL, Gerrard DE. Extracellular signal-regulated kinase pathway is differentially involved in beta-agonist-induced hypertrophy in slow and fast muscles. Am J Physiol Cell Physiol 2007;292:C1681-C1689. [PubMed: 17151143]

46. Thomson DM, Gordon SE. Diminished overload-induced hypertrophy in aged fast-twitch skeletal muscle is associated with AMPK hyperphosphorylation. J Appl Physiol 2005;98:557-564. [PubMed: 15465886]

47. Tidball JG, Lavergne E, Lau KS, Spencer MJ, Stull JT, Wehling M. Mechanical loading regulates NOS expression and activity in developing and adult skeletal muscle. Am J Physiol Cell Physiol 1998;275:C260-C266.

48. Tipton KD, Ferrando AA, Phillips SM, Doyle D Jr, Wolfe RR. Postexercise net protein synthesis in human muscle from orally administered amino acids. Am J Physiol Endocrinol Metab 1999;276:E628-E634.

49. Toyoda T, Tanaka S, Ebihara K, Masuzaki H, Hosoda K, Sato K, Fushiki T, Nakao K, Hayashi T. Low-intensity contraction activates the alpha1-isoform of 5'-AMP-activated protein kinase in rat skeletal muscle. Am J Physiol Endocrinol Metab 2006;290:E583-E590. [PubMed: 16249251]

50. Vandervoort AA. Aging of the human neuromuscular system. Muscle Nerve 2002;25:17-25. [PubMed: 11754180]

51. Volpi E, Ferrando AA, Yeckel CW, Tipton KD, Wolfe RR. Exogenous amino acids stimulate net muscle protein synthesis in the elderly. J Clin Invest 1998;101:2000-2007. [PubMed: 9576765]

52. Volpi E, Kobayashi H, Sheffield-Moore M, Mittendorfer B, Wolfe RR. Essential amino acids are primarily responsible for the amino acid stimulation of muscle protein anabolism in healthy elderly adults. Am J Clin Nutr 2003;78:250-258. [PubMed: 12885705]

53. Wang X, Proud CG. The mTOR pathway in the control of protein synthesis. Physiology 2006;21:362369. [PubMed: 16990457]

54. Welle S, Thornton C, Statt M. Myofibrillar protein synthesis in young and old human subjects after three months of resistance training. Am J Physiol Endocrinol Metab 1995;268:E422-E427.

55. Widegren U, Wretman C, Lionikas A, Hedin G, Henriksson J. Influence of exercise-intensity on ERK/ MAP kinase signalling in human skeletal muscle. Pflügers Arch 2000;441:317-322.

56. Wilkinson SB, Tarnopolsky MA, Macdonald MJ, Macdonald JR, Armstrong D, Phillips SM. Consumption of fluid skim milk promotes greater muscle protein accretion after resistance exercise than does consumption of an isonitrogenous and isoenergetic soy-protein beverage. Am J Clin Nutr 2007;85:1031-1040. [PubMed: 17413102]

57. Williamson D, Gallagher P, Harber M, Hollon C, Trappe S. Mitogen-activated protein kinase (MAPK) pathway activation: effects of age and acute exercise on human skeletal muscle. J Physiol 2003;547:977-987. [PubMed: 12562918]

58. Williamson DL, Kubica N, Kimball SR, Jefferson LS. Exercise-induced alterations in extracellular signal-regulated kinase $1 / 2$ and mammalian target of rapamycin (mTOR) signalling to regulatory mechanisms of mRNA translation in mouse muscle. J Physiol 2006;573:497-510. [PubMed: 16543272]

59. Wojtaszewski JF, Nielsen P, Hansen BF, Richter EA, Kiens B. Iso-form-specific and exerciseintensity-dependent activation of 5'-AMP-activated protein kinase in human skeletal muscle. $\mathrm{J}$ Physiol 2000;528:221-226. [PubMed: 11018120] 
60. Wolfe, RR.; Chinkes, DL. Isotope Tracers in Metabolic Research. Vol. 2nd ed.. Wiley-Liss; Hoboken, NJ: 2005. Calculation of concentration by the internal standard technique; p. 127

61. Yarasheski KE, Zachwieja JJ, Bier DM. Acute effects of resistance exercise on muscle protein synthesis rate in young and elderly men and women. Am J Physiol Endocrinol Metab 1993;265:E210-E214.

62. Yarasheski KE, Pak-Loduca J, Hasten DL, Obert KA, Brown MB, Sinacore DR. Resistance exercise training increases mixed muscle protein synthesis rate in frail women and men $\geq 76 \mathrm{yr}$ old. Am J Physiol Endocrinol Metab 1999;277:E118-E125. 


\section{$\mathrm{EXC}=8$ sets $\mathrm{x} 10$ repetitions \\ (a) 70\% of 1RM}

\section{Prime}

Hours

Biopsy

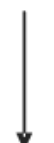

\section{L-[ring ${ }^{2} \mathrm{H}_{5}$ ] phenylalanine}

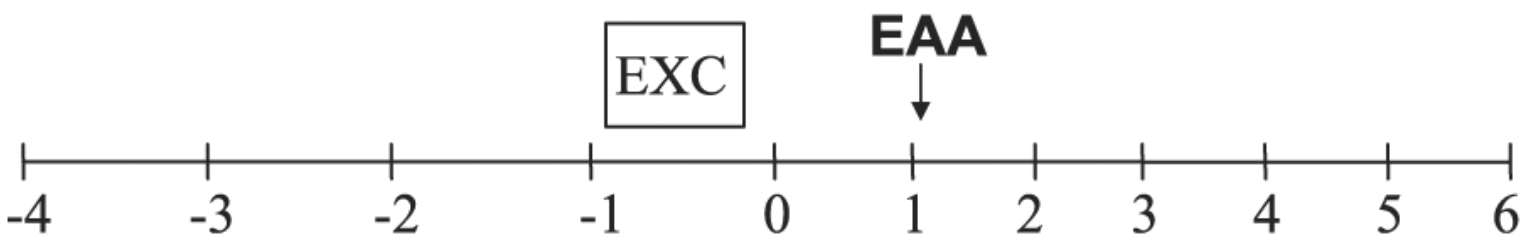

Blood $\uparrow$
Sampling
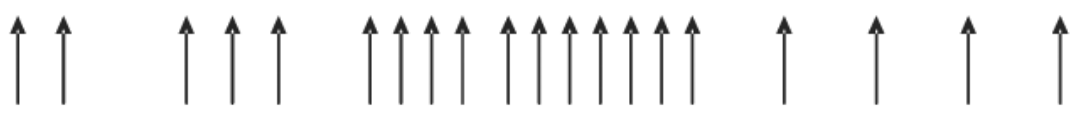

Fig. 1.

Study design. Blood and muscle biopsies were taken at times indicated by arrows. Resistance exercise (Exc) began immediately after the second biopsy. Essential amino acids (EAA) were ingested immediately after the 3rd biopsy ( $1 \mathrm{~h}$ postexercise). 1RM, one-repetition maximum. 


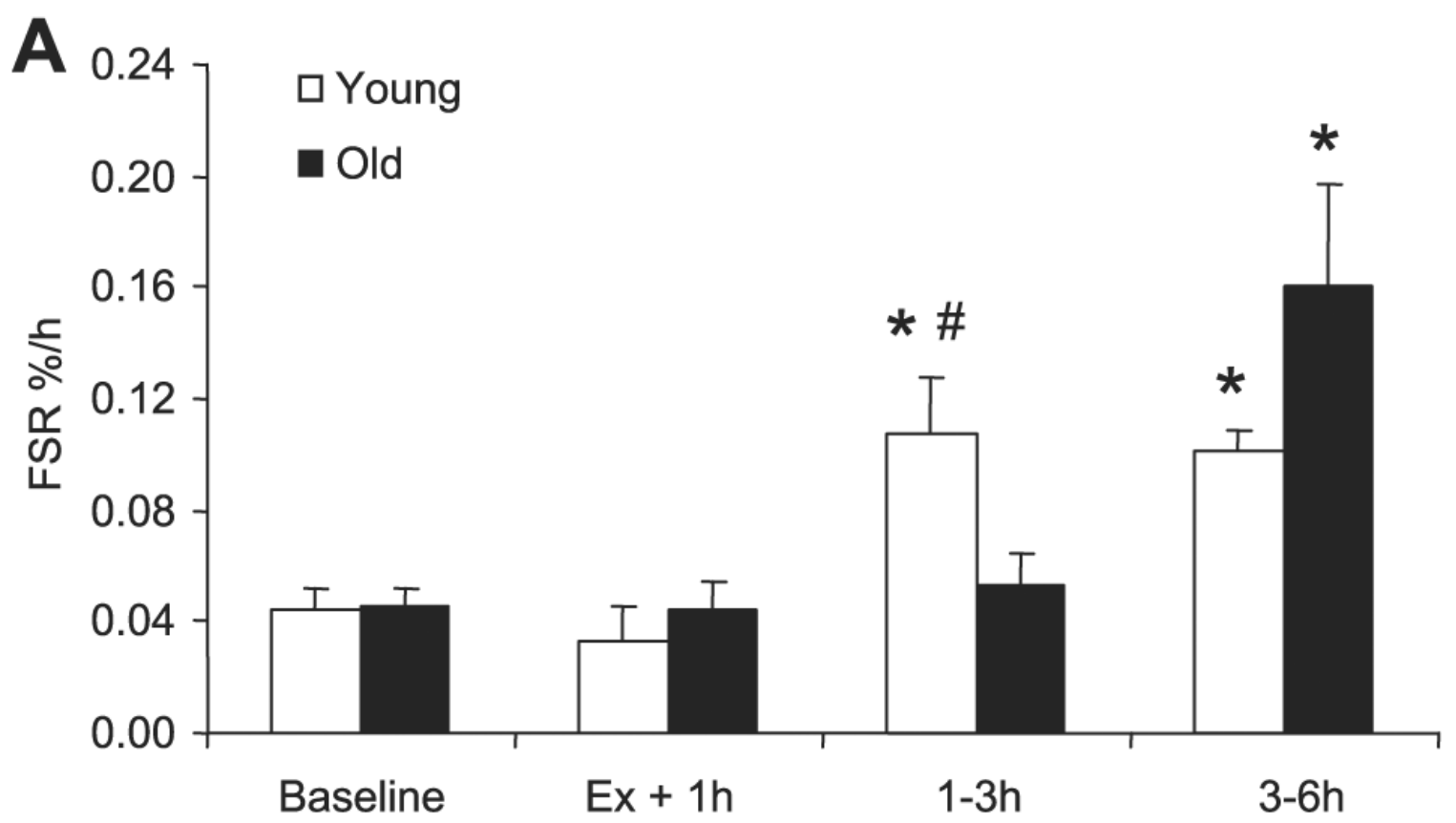

B

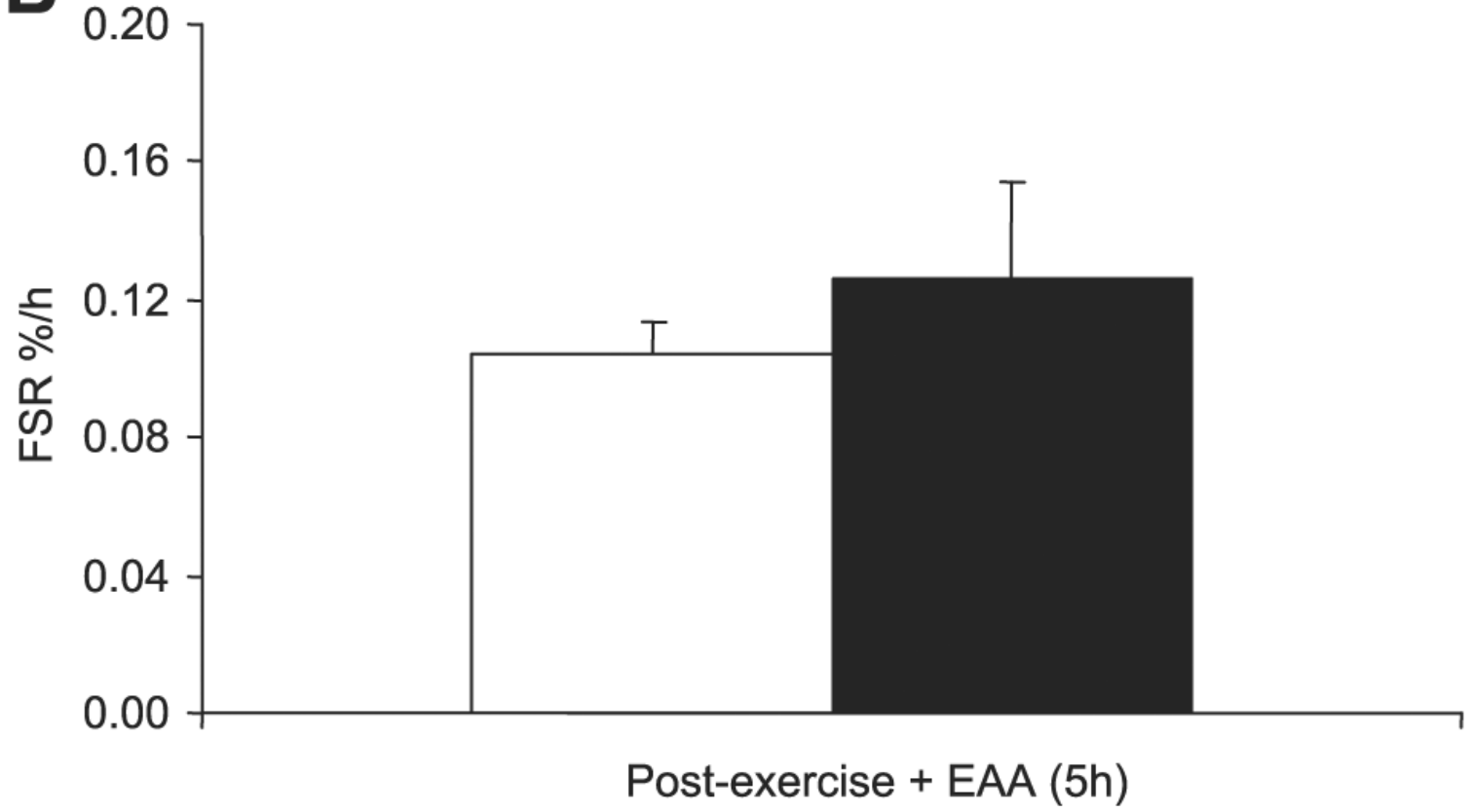

Fig. 2.

$A$ : muscle protein synthesis as expressed by the mixed muscle fractional synthesis rate (FSR) in young $(n=7)$ and old $(n=6)$ subjects at baseline and at exercise $(E x)+1 \mathrm{~h}, 1-3 \mathrm{~h}$, and 3-6 $\mathrm{h}$ after resistance exercise. $B$ : average muscle protein synthesis over a 5 -h period in young and old skeletal muscle after resistance exercise and essential amino acids. *Significantly different from baseline $(P<0.05)$. \#Significantly different from old subjects at corresponding time point $(P<0.05)$. 

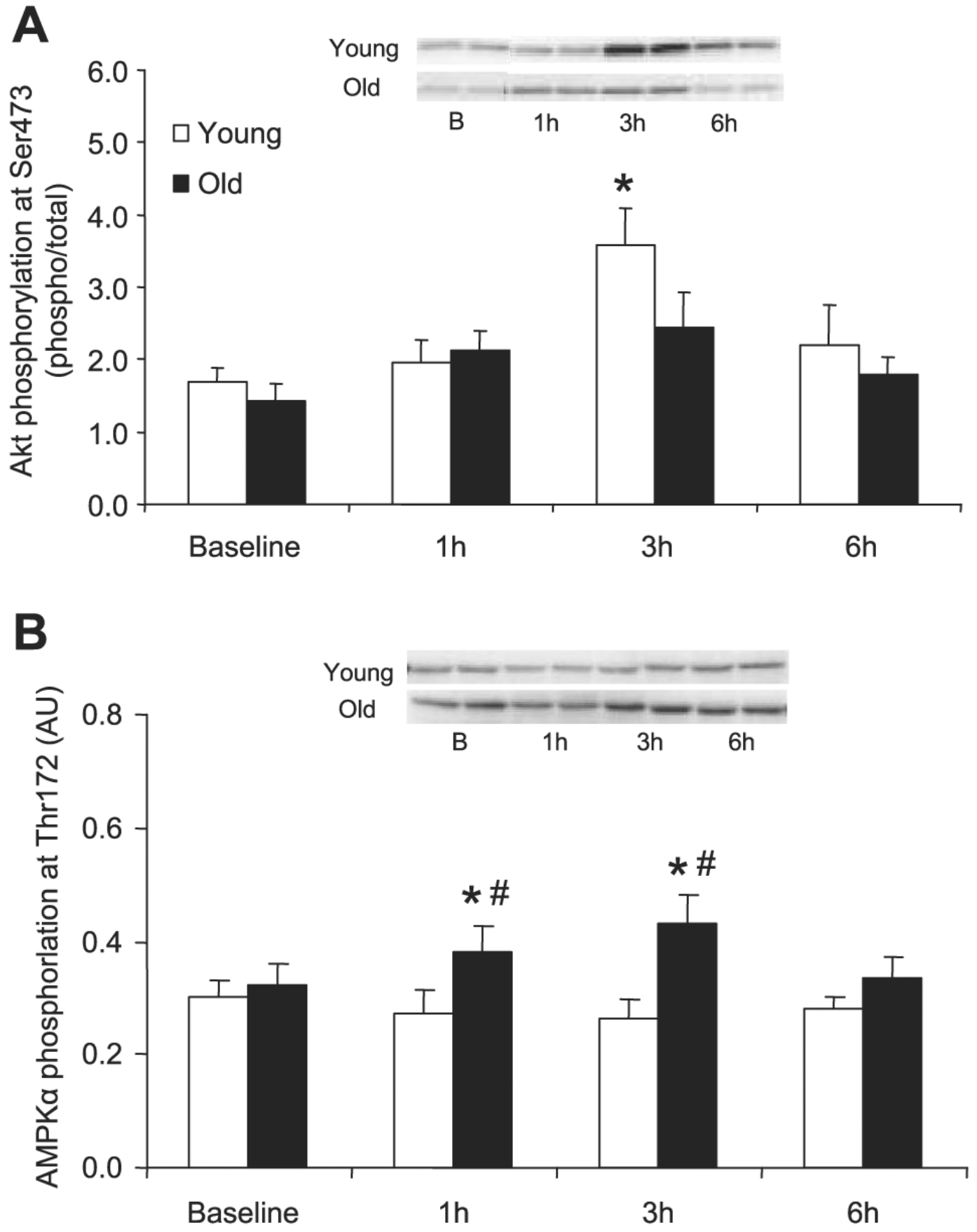

Fig. 3.

Data represent phosphorylation of Akt at Ser473 (young: $n=7$, old: $n=6 ; A$ ) and AMPK $\alpha$ at Thr172 (young: $n=6$, old: $n=6 ; B$ ) between young and old at baseline (B) and 1,3 , and 6 after resistance exercise. Representative immunoblot images are shown above. *Significantly different from baseline $(P<0.05)$. \#Significantly different from young subjects at corresponding time point $(P<0.05)$. 

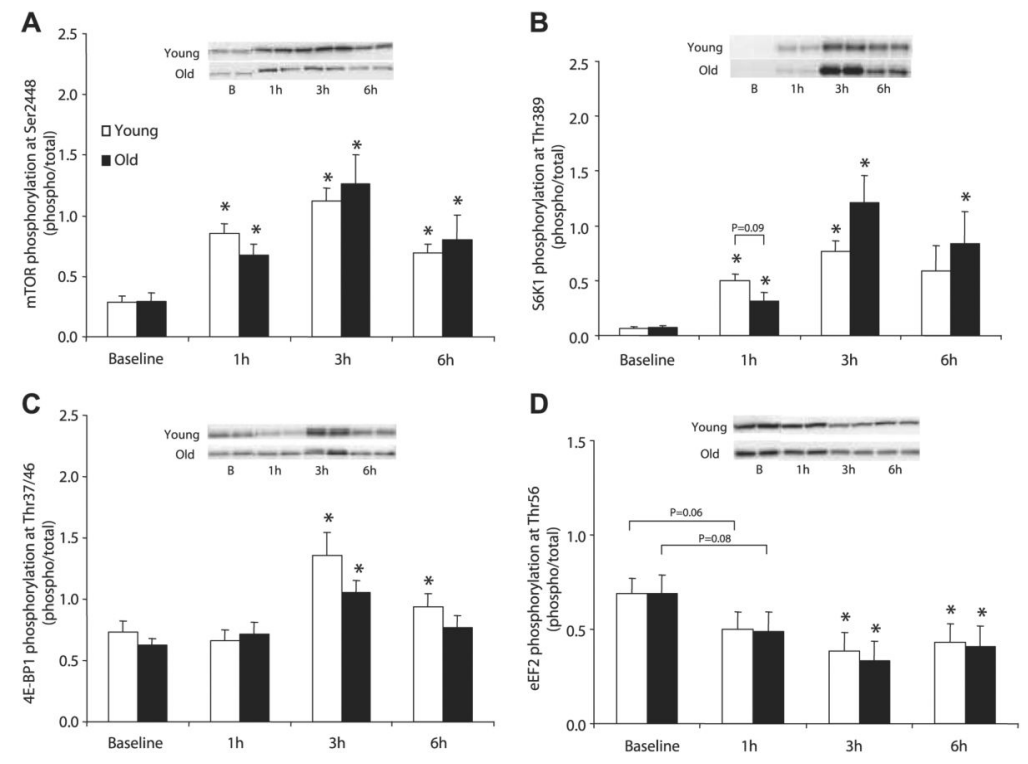

Fig. 4.

Data represent phosphorylation of mTOR at Ser2448 (young: $n=7$, old: $n=6 ; A$ ), S6K1 at Thr389 (young: $n=7$, old: $n=6 ; B$ ), 4E-BP1 at Thr37/46 (young: $n=7$, old: $n=6 ; C$ ), and eEF2 at Thr56 (young: $n=7$, old: $n=6 ; D$ ) between young and old at baseline and 1,3 , and $6 \mathrm{~h}$ after resistance exercise. Representative immunoblot images are shown above.

*Significantly different from baseline $(P<0.05)$. 

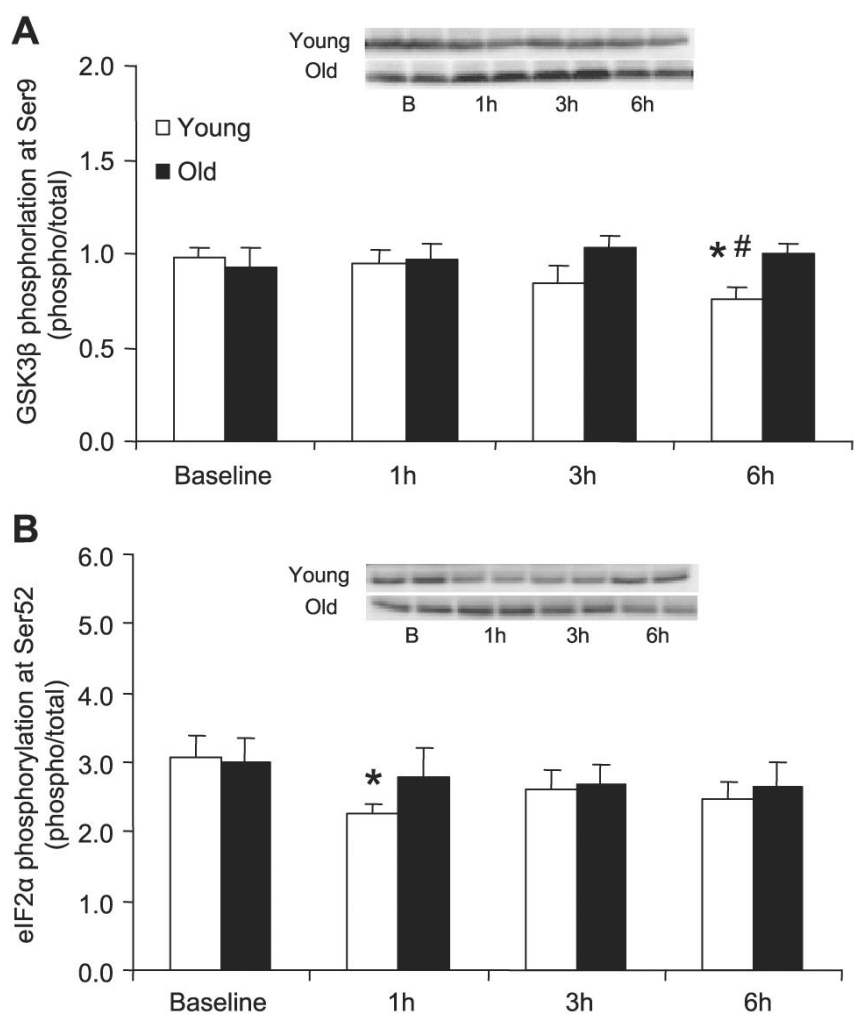

Fig. 5.

Data represent phosphorylation of glycogen synthase kinase $\beta$ (GSK3 $\beta$ ) at Ser9 (young: $n=$ 6, old: $n=6 ; A$ ) and eukaryotic initiation factor $\alpha$ (eIF2 $\alpha$ ) at Ser52 (young: $n=6$, old: $n=6$; $B$ ) between young and old at baseline and 1,3 , and $6 \mathrm{~h}$ postresistance exercise. Representative immunoblot images are shown above. *Significantly different from baseline $(P<0.05)$. \#Significantly different from old subjects at corresponding time point $(P<0.05)$. 

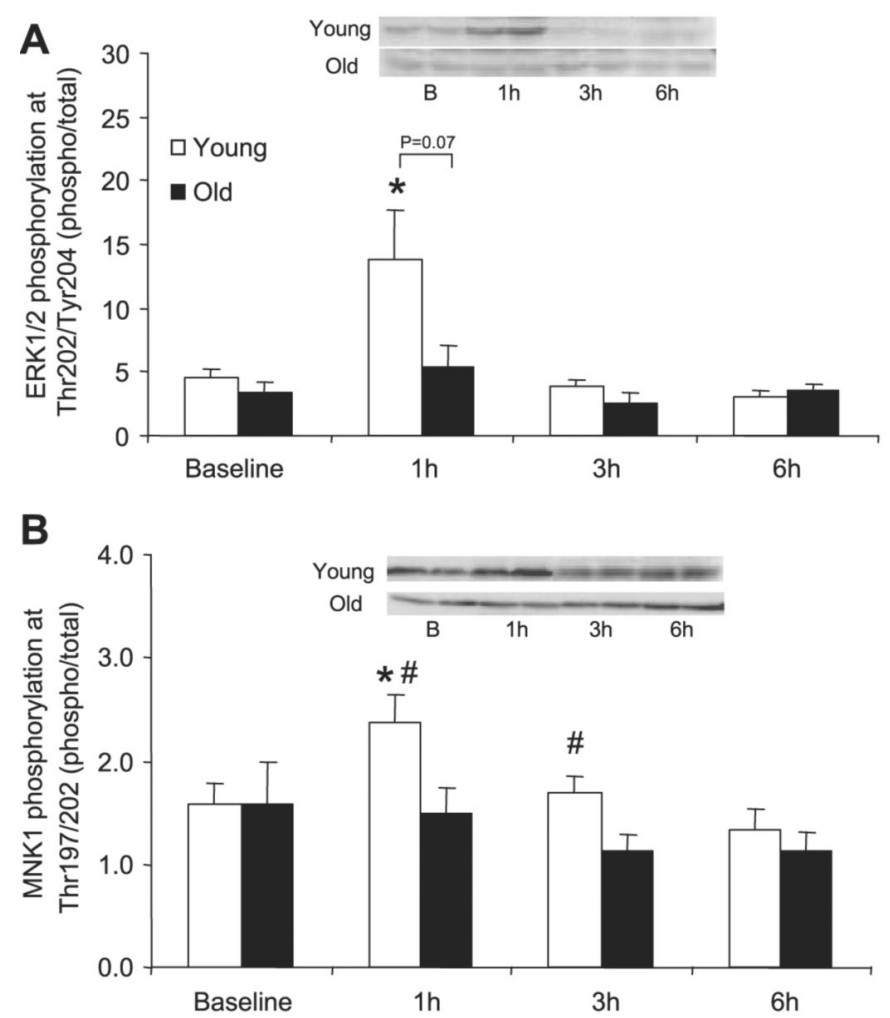

Fig. 6.

Data represent phosphorylation of ERK1/2 at Thr202/Tyr204 (young: $n=6$, old: $n=6 ; A$ ) and MAPK-interacting kinases 1 (MNK1) at Thr197 (young: $n=6$, old: $n=6 ; B$ ) between young and old at baseline and 1, 3, and $6 \mathrm{~h}$ postresistance exercise. Representative immunoblot images are shown above. *Significantly different from baseline $(P<0.05)$. \#Significantly different from old subjects at corresponding time point $(P<0.05)$. 


\section{Subject characteristics}

\section{Table 1}

\begin{tabular}{lrr}
\hline & Young Men $(\boldsymbol{n}=\mathbf{7})$ & Old Men $(\boldsymbol{n}=\mathbf{6})$ \\
\hline Age, yr & $29.7 \pm 1.7^{*}$ & $70.0 \pm 2.1$ \\
Weight, kg & $88.9 \pm 5.4$ & $81.3 \pm 5.2$ \\
Height, cm & $177.1 \pm 2.0$ & $173.5 \pm 3.9$ \\
LM, kg & $64.7 \pm 3.1$ & $59.6 \pm 3.4$ \\
Leg LM, kg; R + & $21.9 \pm 1.1$ & $18.9 \pm 1.1$ \\
FM, kg & $30.5 \pm 7.8$ & $18.8 \pm 2.0$ \\
\%BF, kg & $22.8 \pm 2.8$ & $23.0 \pm 1.3$ \\
Abs. 1RM, kg & $102.6 \pm 8.2^{*}$ & $78.4 \pm 5.2$ \\
Rel. 1RM, 1RM/LM & $1.6 \pm 0.1$ & $1.3 \pm 0.1$ \\
Rel. 1RM, 1RM/Leg LM & $4.7 \pm 0.3$ & $4.2 \pm 0.4$ \\
Average weight lifted/set, N & $705.0 \pm 3.7$ & $466.0 \pm 3.7$ \\
RNA/Protein, $\mu \mathrm{g} / \mathrm{mg}$ & $8.4 \pm 1.3$ & $7.4 \pm 0.7$ \\
\hline
\end{tabular}

Values are means \pm SE. LM, lean mass; R, right leg; L, left leg; FM, fat mass; \%BF, percent body fat; 1RM, one-repetition maximum.

Significantly different from old subjects $(P<0.05)$. 


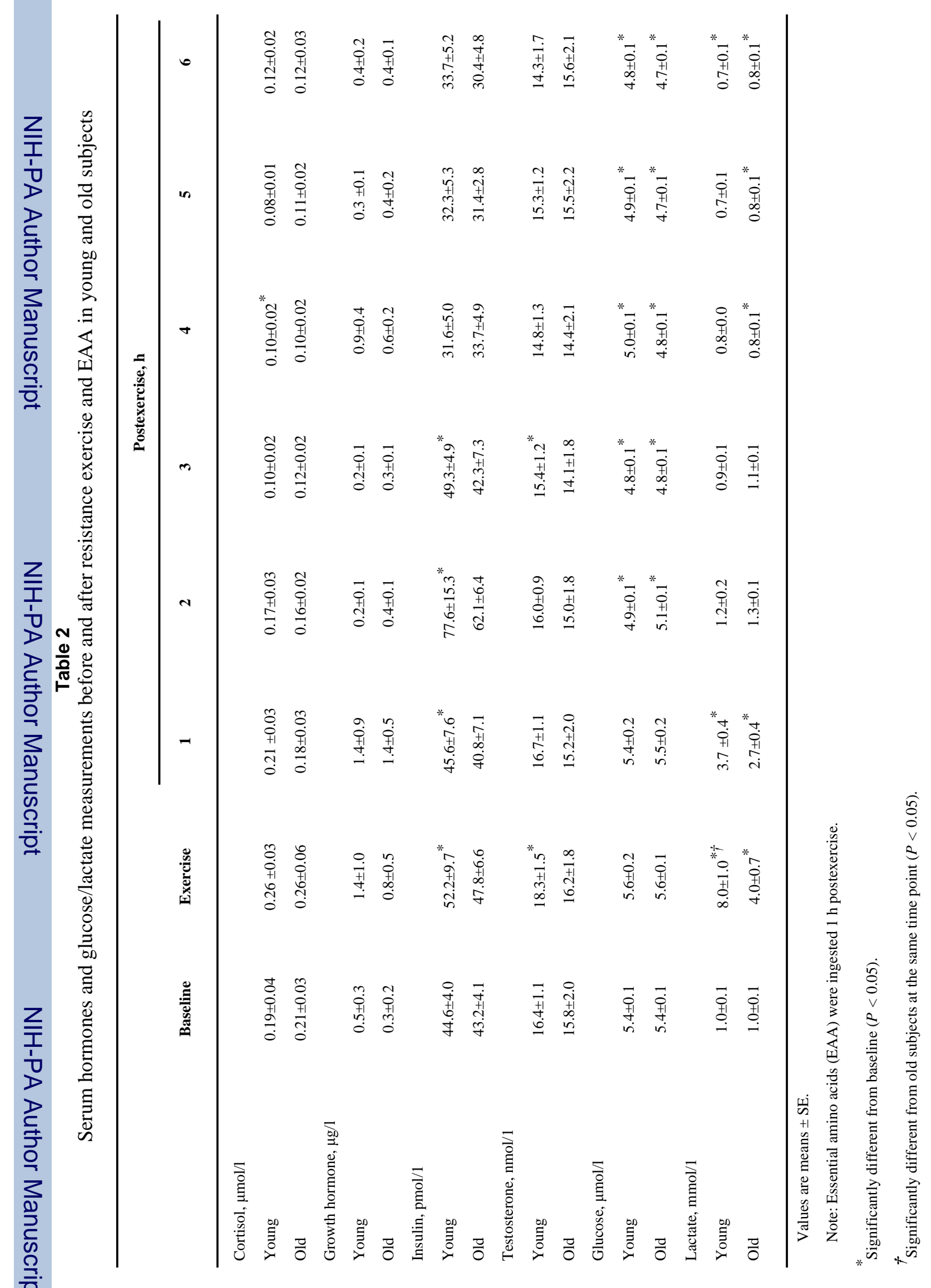




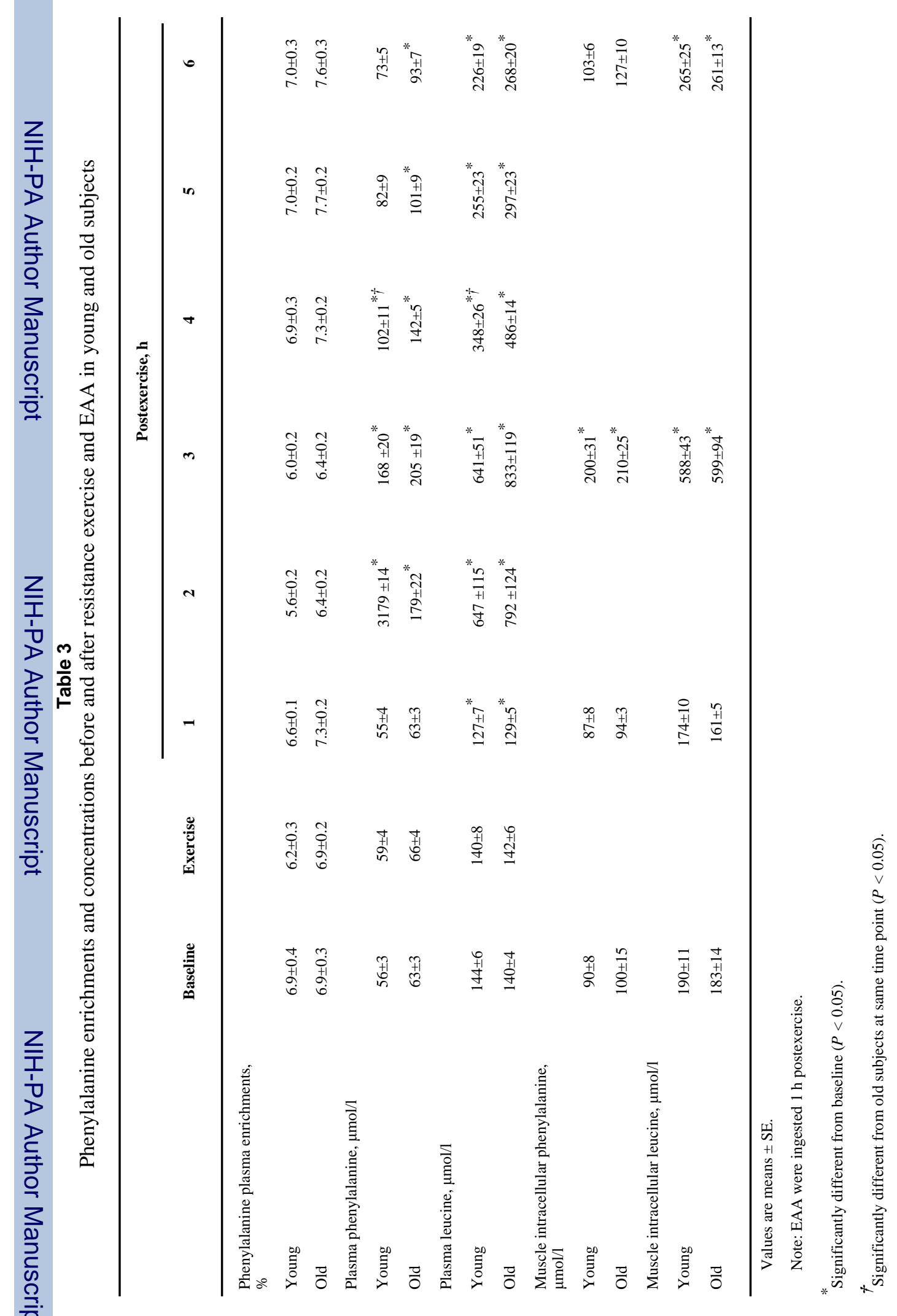

